\title{
Bacterial Endotoxin Test by Gel-Clot Method
}

\author{
Faiz Hashmi, Ankush Thakur
}

QC Microbiologist, Scott-Edil Pharmacia Ltd., Baddi, Himachal Pradesh, India

\begin{abstract}
How to cite this paper: Faiz Hashmi | Ankush Thakur "Bacterial Endotoxin Test by Gel-Clot Method" Published in International Journal of Trend in Scientific Research and Development (ijtsrd), ISSN: 24566470, Volume-3 | Issue-3, April 2019, pp.564-567, URL: http://www.ijtsrd.co $\mathrm{m} /$ papers/ijtsrd229 45.pdf

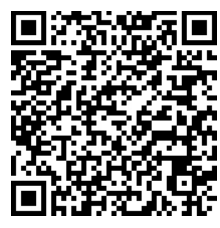
IITSRD22945

Copyright (C) 2019 by author(s) and International Journal of Trend in Scientific Research and Development Journal. This is an Open Access article distributed under the terms of the Creative Commons

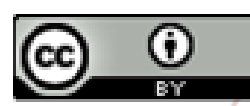
Attribution License (CC BY 4.0) (http://creativecommons.org/licenses/ by/4.0)
\end{abstract}

\section{INTRODUCTION}

Endotoxins are toxic complexes which is invariably associated with the cell-wall of the Gram-negative bacteria irrespective of bacterial pathogenicity. Endotoxins are rarely fatal, but they cause fever and hence Endotoxin carrying bacteria are known as 'Pyrogen'. Endotoxin is toxic substances which is bound with the bacterial cell wall and are released when the bacterium disintegrates. Endotoxin composed of lipopolysaccharide and lipoprotein complexes. The components that are protein determine its antigenic property; and the polysaccharide component determines the antibody type that can react with the Endotoxin molecule. The reaction of polysaccharide components with the Endotoxin when allowed produces an immune reaction. Endotoxin is rarely fatal, although they often cause fever.

Thus, Bacterial Endotoxin test is the confirmatory test that assures the presence or absence of the Endotoxin in the medicine sample. Mostly bacterial Endotoxin test are performed for the inject-able pharmaceutical products, e.g. SWFI (Sterile Water for Injection), Normal Saline (Sodium Chloride Sterile) and other injections like Amikacin sulphate, Ascorbic acid, Esmoprazole sodium, Methylprednisolone, Iron sucrose, Ondansetron, Ranitidine hydrochloride, Thiopental sodium sterile, etc. All these products have their specific Endotoxin limit value determined by 'EU/mg'.

GRAM-NEGATIVE BACTERIA

In the method of bacterial differentiation such bacteria do not retain the crystal violet stain used in the gram-staining.
These bacteria are characterized by their cell envelopes. Their cell wall are composed of a thin peptidoglycan cell-wall sandwiched between an inner cytoplasmic cell membrane and a bacterial outer membrane.

Gram-negative bacteria are found almost everywhere. The gram-negative bacteria include the model organism Escherichia coli, as well as many pathogenic bacteria. Their outer membrane protects them from many antibiotics (including penicillin); detergents that would normally damage the peptidoglycans of the (inner) cell membrane; and lysozyme, an antimicrobial enzyme produced by animals that forms part of the innate immune system. Additionally, the outer leaflet of this membrane comprises a complex lipopolysaccharide (LPS) whose 'lipid A' component can cause a toxic reaction when these bacteria are lysed by immune cells. This toxic reaction can include fever, an increased respiratory rate, and low blood pressure - a lifethreatening condition known as septic shock.

Some examples of Gram-negative bacteria that have demonstrated drug resistance include

$>$ E. coli, which causes the majority of urinary tract infections

$>$ Acinetobacter baumanii, which causes disease mainly in healthcare settings. In addition, wound infections caused by Acinetobacter have been found in U.S. military personnel who were deployed to Iraq and Afghanistan. 
$>$ Pseudomonas aeruginosa, which causes bloodstream infections and pneumonia in hospitalized patients. It is a common cause of pneumonia in patients with cystic fibrosis.

$>$ Klebsiella pneumoniae, which causes many types of healthcare-associated infections, including pneumonia, urinary tract infections, and bloodstream infections

$>$ Neisseria gonorrhoeae, which causes the sexually transmitted disease gonorrhea, is the second most commonly reported infectious disease in the United States.

\section{ENDOTOXINS}

The bacteria those are associated with Endotoxin grows side by side with fungus and or mold in watery environments specifically. These gram negative micro-organisms (bacteria) collectively get accumulated in the human digestive system and thus these microorganisms are responsible for the inflammation in the gut and also in different parts of the body. Endotoxin had been authenticated as inflammatory agent, onset clinical diabetes, obesity, nausea, vomiting, diarrhea, fever, disseminated intravascular coagulation, vascular collapse, and organ failure.

Endotoxins are thus very necessary to get removed eliminated out from the inject-able pharmaceutical products.

\section{AMOEBOCYTE LYSATE}

The term 'lysate' is defined as the mixture of substances which is formed by the lysis of the cells. Amoebocyte lysate is associated with the WBC of horseshoe crab (Limulus polyphemus or Tachypleus tridentatus). Amoebocyte lysate is a lyophilized product procured from the lysate of amoebocyte from the horseshoe crab. Lysate those are obtained from 'Limulus polyphemus' is known as 'Limulus Amoebocyte Lysate', while lysate those are obtained from 'Tachypleus tridentatus' is known as 'Tachypleus Amoebocyte Lysate'. Amoebocyte lysate is needed to be dissolved in the water associated with the types of lysate e.g. for 'Limulus
Amoebocyte Lysate' the water that is needed to reconstitute the lysate is thus 'LAL Reagent Water' whereas for 'Tachypleus Amoebocyte Lysate' the water that is needed to reconstitute the lysate is thus 'TAL Reagent Water'. Lysate is lypholilized and it should be stored at $2-8^{0} \mathrm{C}$.

\section{LYSATE VALIDATION}

Lysate validation is a no touch technique. It directs towards the preparation of 'Control Standard Endotoxin' (CSE). Before the preparation of 'Control Standard Endotoxin' (CSE), first we need to check the 'Certificate of Analysis' (CoA) and needed to match the Standard Endotoxin, LAL Reagent Water and Lysate. Thereafter the reconstitution of CSE shall be conducted. The following steps are required to be followed for the reconstitution of CSE, or in other words for the 'Lysate Validation':

1. CSE is needed to be reconstituted with the $5 \mathrm{ml}$ of LAL Reagent Water (LRW).

2. It is then vortexed for about $15 \mathrm{~min}$. Reconstituted CSE can be stored at $4^{\circ} \mathrm{C}$ for 28 days and every time when it has to used always vortex it for $15 \mathrm{~min}$ before use.

3. If the given Concentration is $20 \mathrm{EU} / \mathrm{ml}$ according to the $\mathrm{CoA}$, then the dilution of $1 \mathrm{Eu} / \mathrm{ml}$ can be prepared using the following process:

Took $100 \mu \mathrm{l}$ or $0.1 \mathrm{ml}$ of CSE and Mix $1.9 \mathrm{ml}$ of LRW $100 \mu \mathrm{l} \mathrm{CSE}+1.9 \mathrm{ml}$ of $\mathrm{LRW}=1 \mathrm{Eu} / \mathrm{ml}$

4. If the given Concentration is $22 \mathrm{EU} / \mathrm{ml}$ according to the $\mathrm{CoA}$, then the dilution of $1 \mathrm{Eu} / \mathrm{ml}$ can be prepared using the following process:

In $100 \mu \mathrm{l}$ or $0.1 \mathrm{ml}$ of CSE and Mix $2.1 \mathrm{ml}$ of LRW $100 \mu \mathrm{l} \mathrm{CSE}+2.1 \mathrm{ml}$ of $\mathrm{LRW}=1 \mathrm{Eu} / \mathrm{ml}$

5. After then the dilution is thus being prepared by the following dilution process.

Table-01

\begin{tabular}{|c|c|c|c|}
\hline Dilution Process & Identifiers & Concentration (EU/ml) & Sensitivity $\lambda$ \\
\hline $0.1 \mathrm{ml}(20 \mathrm{EU}$ CSE) + 1.9 ml of LRW & $\mathrm{A}$ & 1 & $8 \lambda$ \\
\hline $1 \mathrm{ml}(\mathrm{A})+1 \mathrm{ml}$ of LRW & $\mathrm{B}$ & 0.5 & $4 \lambda$ \\
\hline $1 \mathrm{ml}(\mathrm{B})+1 \mathrm{ml}$ of LRW & $\mathrm{C}$ & 0.25 & $2 \lambda$ \\
\hline $1 \mathrm{ml}(\mathrm{C})+1 \mathrm{ml}$ of LRW & $\mathrm{D}$ & 0.125 & $\lambda$ \\
\hline $1 \mathrm{ml}(\mathrm{D})+1 \mathrm{ml}$ of LRW & $\mathrm{E}$ & 0.06 & $\lambda / 2$ \\
\hline $1 \mathrm{ml}(\mathrm{E})+1 \mathrm{ml}$ of LRW & $\mathrm{F}$ & 0.03 & $\lambda / 4$ \\
\hline
\end{tabular}

\section{LYSATE RECONSTITUTION}

1. While proceeding towards the Lysate reconstitution, the label of the Lysate is needed to be checked first.

2. If the label of the Lysate indicates $1.8 \mathrm{ml}$, then it signifies that it is for 16 tests from now.

3. Lysate is thus being reconstituted by adding $1.8 \mathrm{ml}$ of LRW. After the addition of LRW to the Lysate, it is required to 'swirl gently and not to vortex it'.

4. If the label of the Lysate indicates $5.2 \mathrm{ml}$, then it signifies that it is for 50 tests from now.

5. Lysate is thus being reconstituted by adding $5.2 \mathrm{ml}$ of LRW. After the addition of LRW to the Lysate, it is required to 'swirl gently and not to vortex it'.

Reconstituted Lysate can be stored for 24 hours at $2^{\circ} \mathrm{C}-8^{\circ} \mathrm{C}$. For longer storage, reconstituted Lysate can be stored at $-8^{\circ} \mathrm{C}$ or lesser than this temperature.

This test should be in Quadruplicate reaction tube to be conducted by Following Process: 
International Journal of Trend in Scientific Research and Development (IJTSRD) @ www.ijtsrd.com eISSN: 2456-6470

Table-02

\begin{tabular}{|c|c|c|c|}
\hline Lysate Sensitivity & CSE Quantity & Lysate Quantity & Result \\
\hline $2 \lambda(4$ tubes $)$ & $0.1 \mathrm{ml}$ of sample C from Table- 01 & $0.1 \mathrm{ml}$ of Lysate & $+\mathrm{ve}$ \\
\hline$\lambda(4$ tubes $)$ & $0.1 \mathrm{ml}$ of sample D from Table- 01 & $0.1 \mathrm{ml}$ of Lysate & $+\mathrm{ve} /$-ve \\
\hline$\lambda / 2(4$ tubes $)$ & $0.1 \mathrm{ml}$ of sample E from Table- 01 & $0.1 \mathrm{ml}$ of Lysate & $+\mathrm{ve} /$-ve \\
\hline$\lambda / 4(4$ tubes $)$ & $0.1 \mathrm{ml}$ of sample F from Table- 01 & $0.1 \mathrm{ml}$ of Lysate & -ve \\
\hline NC $(4$ tubes $)$ & $0.1 \mathrm{ml}$ of LRW & $0.1 \mathrm{ml}$ of Lysate & -ve \\
\hline
\end{tabular}

This test is also known as the 'Assay Test'.

Here, NC stands for the Negative Control.

1. After the preparation of the dilution according to the Table-02, all the respective reaction tubes are incubated for 60 minutes, at $37^{\circ} \mathrm{C}$, in the heating mantle.

2. After the completion of 60 minutes, the incubation of the reaction tubes are over, and thus it is necessary to remove the reaction tubes one by one carefully and is inverted about $180^{\circ}$.

3. The tubes are then to be observed and the result of the reaction in each of the respective tubes has to be recorded. As if the clot formation takes place in the reaction tubes, then it means Endotoxin was present in that reaction tube and thus the result is considered to be positive. And if the clot formation doesn't takes place, then it means Endotoxin was absent in that reaction tube and thus the result is considered to be negative.

\section{MAXIMUM VALID DILLUTION (MVD)}

The maximum allowable dilution of a sample at which the Endotoxin Limit can be determined is known as the maximum valid dilution.

MVD = (endotoxin limit $\mathrm{X}$ concentration of sample solution $) /(\lambda)$

\section{ENDOTOXIN LIMIT}

The endotoxin limit of parenteral drug, defined on the basis of dose, equals $K / M^{2}$, where $K$ is a threshold pyrogenic dose of endotoxin per kg of body weight. When the product is injected at frequent intervals or infused continuously, $M$ is the maximum total dose administered in a single hour period. The endotoxin limit of the parenteral drugs is specified in the individual monograph in units such as $\mathrm{EU} / \mathrm{ml}, \mathrm{EU} / \mathrm{mg}$, EU/Unit of biological activity, etc.

Parenteral drugs are the sterile preparations containing one or more active ingredients intended to be administered to a patient other than the alimentary canal (gastrointestinal tract) routes.

The concentration of the sample solution:

1. $\mathrm{mg} / \mathrm{ml}$ : in the case of endotoxin limit particularized by weight (EU/mg);

2. $\mathrm{ml} / \mathrm{ml}$ : in the case of endotoxin limit particularized by volume $(\mathrm{EU} / \mathrm{ml})$;

3. Units/ml: in the case of endotoxin limit particularized by unit of biological activity (EU/unit);
4. $\lambda$ : the labeled sensitivity in the Gel-Clot technique $(\mathrm{EU} / \mathrm{ml})$.

Following are the few parenteral drugs raw material and their endotoxin limits:

\begin{tabular}{|c|c|c|}
\hline $\begin{array}{l}\text { S. } \\
\text { No. }\end{array}$ & Raw Material & $\begin{array}{l}\text { BET Limit } \\
\text { (EU/mg) }\end{array}$ \\
\hline 1. & Amikacin sulphate inj. & 0.33 \\
\hline 2. & Ascorbic acid inj. & 1.2 \\
\hline 3. & Esmoprazole sodium sterile & 0.125 \\
\hline 4. & Methylprednisolone & 0.17 \\
\hline 5. & Iron sucrose & 3.7 \\
\hline 6. & Ondansetron inj. & 9.9 \\
\hline 7. & Ranitidine hydrochloride inj. & 7.0 \\
\hline 8. & Thiopental sodium sterile & 1.0 \\
\hline 9. & Triamcinolone acetonide inj. & 4.4 \\
\hline 10. & $\begin{array}{l}\text { Hydrocortisone sod. succinate } \\
\text { sterile }\end{array}$ & 1.25 \\
\hline 11. & Rabeprazole & 0.125 \\
\hline 12. & Pantoprazole & 0.20 \\
\hline 13. & Omeprazole & 0.125 \\
\hline 14. & Vancomycin sodium sterile & 0.25 \\
\hline 15. & Gentamycin sulphate sterile & 1.67 \\
\hline 16. & Dexamethasone & 31.3 \\
\hline 17. & Sodium chloride & 0.25 \\
\hline 18. & Cefoperazone \& sulbactum inj & 0.17 \\
\hline 19. & Ceftriaxone inj. & 0.20 \\
\hline 20. & Cefotaxime sodium & 0.20 \\
\hline 21. & Ceftazidime inj. & 0.17 \\
\hline 22. & Cefuroxime inj. & 0.1 \\
\hline 23. & Sterile Water for Injection & 0.25 \\
\hline 24. & Paracetamol infusion & 2.0 \\
\hline 25. & Lignocaine & 1.1 \\
\hline 26. & Piperacillin tazobactum & 0.08 \\
\hline 27. & Artisunate & 1.25 \\
\hline 28. & Meropenem & 0.125 \\
\hline 29. & Sodium bicarbonate & 1.7 \\
\hline 30. & Flucloxacillin sodium & 0.2 \\
\hline 31. & Dicyclomine HCl & 17.2 \\
\hline 32. & Ampilon & 0.15 \\
\hline 33. & Monoasthal & 1.0 \\
\hline 34. & Iron dextrose & 0.05 \\
\hline 35. & $\begin{array}{l}\text { Betamethasone sodium } \\
\text { phosphate }\end{array}$ & 29.2 \\
\hline 36. & Tobramycin sulphate & 2.0 \\
\hline 37. & Hyoscine-N-Butylbromide & 1.94 \\
\hline
\end{tabular}

\section{DILLUTION PREPARATION TECHNIQUE GEL-CLOT TECHNIQUE}

Table-04

\begin{tabular}{|c|c|c|c|c|c|}
\hline Test for product & LRW $(\mu \mathrm{l})$ & CSE $(\boldsymbol{\mu l})(\mathbf{4} \boldsymbol{\lambda})$ & Sample $(\boldsymbol{\mu l})$ & Lysate $(\boldsymbol{\mu l})$ & Observation \\
\hline Negative water Control & 100 & ---- & ---- & 100 & - Ve \\
\hline Negative Product Control & 50 & ---- & 50 & 100 & $-\mathrm{Ve}$ \\
\hline Positive water Control & 50 & 50 & ---- & 100 & $+\mathrm{Ve}$ \\
\hline Positive Product Control & ---- & 50 & 50 & 100 & $+\mathrm{Ve}$ \\
\hline
\end{tabular}


International Journal of Trend in Scientific Research and Development (IJTSRD) @ www.ijtsrd.com eISSN: 2456-6470

Table-05

\begin{tabular}{|c|c|c|c|c|c|}
\hline Test for SWFI & LRW $(\boldsymbol{\mu l})$ & CSE $(\boldsymbol{\mu l})(\mathbf{2 0 \lambda})$ & Sample $(\boldsymbol{\mu l})$ & Lysate $(\boldsymbol{\mu l})$ & Observation \\
\hline Negative water Control & 100 & --- & ---- & 100 & $-\mathrm{Ve}$ \\
\hline Negative Product Control & ---- & ---- & 100 & 100 & $-\mathrm{Ve}$ \\
\hline Positive water Control & 100 & 10 & ---- & 100 & $+\mathrm{Ve}$ \\
\hline Positive Product Control & ---- & 10 & 100 & 100 & $+\mathrm{Ve}$ \\
\hline
\end{tabular}

\section{OBSERVATION}

1. All the respective reaction tubes are incubated for 60 minutes, at $37^{\circ} \mathrm{C}$, in the heating mantle.

2. After the completion of 60 minutes, the incubation of the reaction tubes are over, and thus it is necessary to remove the reaction tubes one by one carefully and is inverted about $180^{\circ}$.

3. The tubes are then to be observed and the result of the reaction in each of the respective tubes has to be recorded. As if the clot formation takes place in the reaction tubes, then it means Endotoxin was present in that reaction tube and thus the result is considered to be positive. And if the clot formation doesn't takes place, then it means Endotoxin was absent in that reaction tube and thus the result is considered to be negative.

\section{REFERENCES}

[1] C2011 United States Pharmacopeial Convention

[2] http://ntced.org/diagnosing-moldexposure/endotoxins/

[3] https://www.britannica.com/science/endotoxin

[4] https://en.wikipedia.org/wiki/Limulus_Amebocyte_Ly sate

[5] (C)2018, Indian Pharmacopoeia Commission

[6] http://parenteraldrug.com/

[7] https://www.niaid.nih.gov/research/gram-negativebacteria

[8] https://en.wikipedia.org/wiki/Gram-negative_bacteria

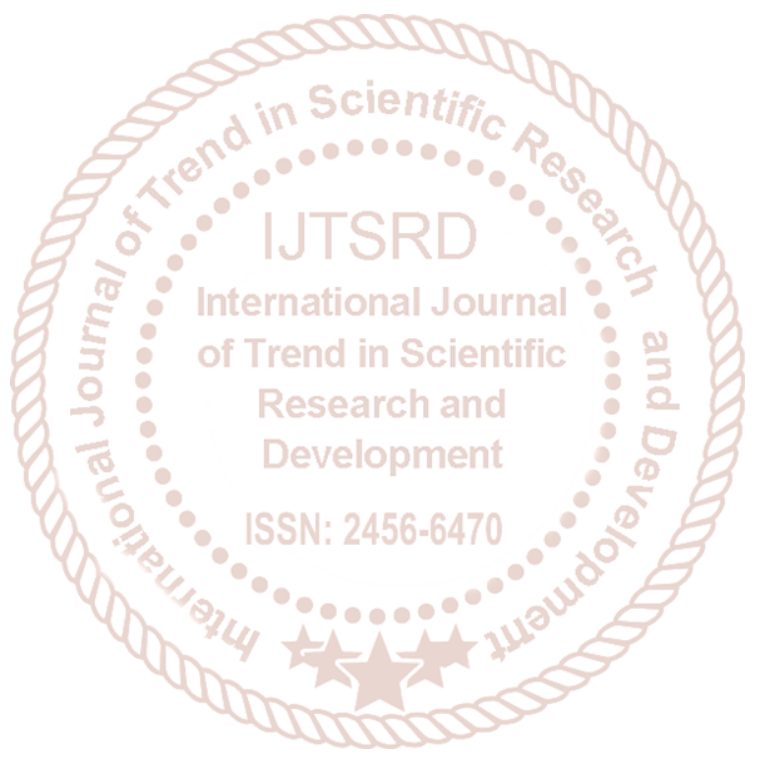

